\title{
A STUDY OF CONSUMER INFORMATION LITERACY BY INFORMATION SEARCH TYPE
}

\author{
Yu Lim Lee and Jae-Eun Chung \\ Department of Consumer \& Family Science, Sungkyunkwan University, Korea \\ 25-2, Sungkyunkwan-ro, Jongno-gu, Seoul, Republic of Korea
}

\begin{abstract}
The purpose of this study is to classify consumers in their twenties and thirties based on information channel use and to examine the differences in consumer information literacy across clusters. Cluster analysis on use of fourteen information channels, performed on 320 Korean consumers between the ages of 20 and 39, identified four clusters. ANOVA and post-hoc analysis revealed that all subdimensions of consumer information literacy, including task definition, information seeking strategies, location and access, use of information synthesis, and evaluation, were significantly different across the clusters. Managerial and theoretical implications are provided based on the results.
\end{abstract}

\section{KEYWORDS}

Information Search, Consumer Information Literacy, Multi-Channel, Information Channel

\section{INTRODUCTION}

As forms of media become more diverse and the amount of information increases due to the rapid growth of information technology, consumers are being surrounded by a more complicated information environment. Because consumers are required to screen, select, and use precise information to make purchase decisions (Hwang and Kim, 2012), it is necessary to understand how consumers search information and what level of information-search capabilities they have in the deluge of information. Therefore, this study aims to classify consumers in their twenties and thirties based on information channel use and to understand the differences in consumer information literacy (CIL) across clusters.

\section{RESEARCH METHODS}

A survey based on self-administrated questionnaires was carried out with South Korean consumers in their twenties and thirties who had purchased a laptop computer in the past year. All questionnaires were distributed and collected via online media. After deleting thirteen incomplete responses, a total of 320 questionnaires were used for analysis.

Pre-established measurements were employed to measure the relevant constructs. First, respondents were asked to indicate how often they used each of the fourteen information channels to purchase a laptop computer with a five-point Likert-type scale ranging from 'not at all' to 'very often.' These information channels were selected based on Lee and Rha (2012)'s study. In order to measure CIL, the Korean version of Big 6 Skills scale (Kang, 2010) was used. This scale includes a total of eighteen items and consists of six sub-dimensions: task definition, information seeking strategies, location and access, use of information, synthesis, and evaluation. Items for CIL were measured on a seven-point Likert-type scale ranging from 'strongly disagree' to 'strongly agree.'

In order to classify homogeneous groups of consumers based on the use of information channels, cluster analysis with non-hierarchical classification procedure (k-means cluster analysis) was conducted. Cross-tabulation analysis was performed to examine demographic characteristics of the final clusters. ANOVA and Duncan's post-hoc test were used to examine the differences in the level of CIL among the groups. All analyses were conducted by SPSS 20.0. 


\section{RESULTS}

As shown in Table 1, results of the cluster analysis revealed that consumers in their twenties and thirties fell under four clusters. "Price-comparison-site seekers" explored the least amount of information and relied mostly on price comparison websites. "Information checkers" tended to confirm information by visiting brick-and-mortar stores and acquaintances. "Consumer information seekers" heavily relied on information channels in which the information providers were other consumers. "Heavy searchers" actively utilized most of the information channels. There was a significant difference between clusters with respect to respondents' average monthly income $\left(\chi^{2}=24.74, \mathrm{p}<.01\right)$ but there were no differences in gender, age and education level. 'Price comparison site seeker' consisted of respondents with relatively low income (under $\$ 1,000$ ). On the contrary, respondents with high income (over $\$ 5,001 \$$ ) tended to belong to 'heavy searcher.'

Table 1. Results of cluster analysis

\begin{tabular}{|c|c|c|c|c|c|c|c|c|c|c|}
\hline \multicolumn{2}{|c|}{ Information channels } & \multicolumn{2}{|c|}{$\begin{array}{c}\text { Cluster } 1 \\
(\mathrm{n}=42) \\
\text { Price-comparison- } \\
\text { site seeker }\end{array}$} & \multicolumn{2}{|c|}{$\begin{array}{c}\text { Cluster 2 } \\
(\mathrm{n}=82) \\
\text { Information } \\
\text { checker }\end{array}$} & \multicolumn{2}{|c|}{$\begin{array}{c}\text { Cluster } 3 \\
(\mathrm{n}=85) \\
\text { Consumer } \\
\text { information seeker }\end{array}$} & \multicolumn{2}{|c|}{$\begin{array}{c}\text { Cluster } 4 \\
(\mathrm{n}=111) \\
\text { Heavy } \\
\text { searcher }\end{array}$} & \multirow{2}{*}{$\begin{array}{c}\mathrm{F} \\
29.77^{* * *}\end{array}$} \\
\hline \multirow{2}{*}{$\begin{array}{l}\text { Online- } \\
\text { Seller }\end{array}$} & $\begin{array}{l}\text { Web site and SNS } \\
\text { of manufacturer }\end{array}$ & $2.01(.89)$ & $\mathrm{a}$ & $2.63(.72)$ & $\mathrm{b}$ & $2.61(.88)$ & $\mathrm{b}$ & $3.35(.89)$ & $\mathrm{c}$ & \\
\hline & $\begin{array}{l}\text { Online shopping } \\
\text { mall }\end{array}$ & $3.48(1.15)$ & $\mathrm{a}$ & $3.57(.72)$ & a & $4.00(.79)$ & $\mathrm{b}$ & $4.20(.70)$ & $b$ & $13.89^{* * *}$ \\
\hline \multirow{4}{*}{$\begin{array}{l}\text { Offline- } \\
\text { seller }\end{array}$} & TV commercial & $1.55(.77)$ & $\mathrm{a}$ & $3.00(.66)$ & $\mathrm{c}$ & $1.97(.70)$ & $\mathrm{b}$ & $3.41(80)$ & d & $101.49^{* * *}$ \\
\hline & Brand event & $1.40(.50)$ & $\mathrm{a}$ & $2.73(.58)$ & $\mathrm{c}$ & $1.86(.60)$ & $\mathrm{b}$ & $3.09(69)$ & $d$ & $110.36^{* * *}$ \\
\hline & Clerk & 1.61(.79) & $\mathrm{a}$ & $3.10(.71)$ & $\mathrm{c}$ & $2.16(1.02)$ & $\mathrm{b}$ & $3.44(.67)$ & $d$ & $76.56^{* * *}$ \\
\hline & Home shopping & $1.50(.97)$ & $\mathrm{a}$ & $2.85(.97)$ & $\mathrm{c}$ & $1.85(.91)$ & $\mathrm{b}$ & $3.23(.95)$ & $d$ & $54.8^{* * *}$ \\
\hline \multirow{3}{*}{$\begin{array}{l}\text { Online- } \\
\text { consumer }\end{array}$} & Review & $2.91(1.06)$ & $\mathrm{a}$ & $2.95(.65)$ & $\mathrm{a}$ & $3.93(.65)$ & $\mathrm{b}$ & $4.0(.60)$ & $\mathrm{b}$ & $55.57^{* * *}$ \\
\hline & Portal site & $2.67(1.10)$ & $\mathrm{a}$ & $2.81(.87)$ & a & $3.45(.85)$ & $\mathrm{b}$ & $3.87(.79)$ & $\mathrm{c}$ & $33.03^{* * *}$ \\
\hline & SNS & $1.81(.74)$ & $\mathrm{a}$ & $2.38(.86)$ & $\mathrm{b}$ & $2.77(1.00)$ & $\mathrm{c}$ & $3.63(.82)$ & $d$ & $58.18^{* * *}$ \\
\hline \multirow{2}{*}{$\begin{array}{l}\text { Offline- } \\
\text { consumer }\end{array}$} & Acquaintance & $1.76(.96)$ & a & $3.17(.70)$ & $\mathrm{b}$ & $3.87(.88)$ & $\mathrm{c}$ & $4.02(.65)$ & $\mathrm{c}$ & $98.68^{* * *}$ \\
\hline & Observing others & $1.67(.82)$ & a & $2.82(.69)$ & $\mathrm{b}$ & $3.32(.86)$ & $\mathrm{c}$ & $3.65(.63)$ & d & $80.08^{* * *}$ \\
\hline \multirow{2}{*}{$\begin{array}{l}\text { Online- } \\
\text { neutral }\end{array}$} & $\begin{array}{c}\text { News and } \\
\text { magazine articles }\end{array}$ & $1.76(.93)$ & $\mathrm{a}$ & $2.68(.83)$ & $\mathrm{c}$ & $2.28(.81)$ & $\mathrm{b}$ & $3.67(.67)$ & d & $82.28^{* * *}$ \\
\hline & $\begin{array}{l}\text { Price-comparison- } \\
\text { site }\end{array}$ & $3.50(1.25)$ & $\mathrm{a}$ & $3.34(.89)$ & a & $4.02(.84)$ & $\mathrm{b}$ & $4.06(.85)$ & $\mathrm{b}$ & $12.97^{* * *}$ \\
\hline $\begin{array}{l}\text { Offline- } \\
\text { neutral }\end{array}$ & $\begin{array}{c}\text { News and } \\
\text { magazine articles }\end{array}$ & $1.48(.71)$ & $\mathrm{a}$ & $2.79(.84)$ & $\mathrm{c}$ & $1.94(.84)$ & $\mathrm{b}$ & $3.38(.85)$ & d & $77.86^{* * *}$ \\
\hline \multicolumn{2}{|c|}{$\begin{array}{l}\text { Mean of overall information } \\
\text { channels use }\end{array}$} & 29.10 & $\mathrm{a}$ & 40.82 & $\mathrm{~b}$ & 40.01 & $\mathrm{~b}$ & 51.01 & $\mathrm{c}$ & $302.02^{* * *}$ \\
\hline
\end{tabular}

The results of ANOVA and post-hoc analysis showed that there were significant differences between the clusters in overall levels of CIL and its six subdimensions, as shown in Table 2. Consumer information seekers and heavy searchers had higher levels of overall CIL than did price-comparison-site seekers and information checkers. Specifically, heavy searchers showed the highest level across all subdimensions of CIL. This indicated that, as these consumers had the ability to identify what information was needed and which information channels they could explore, heavy searchers actively explored diverse information channels to obtain the information they deemed appropriate. Also, information checkers had the lowest score on task definition, which is the ability to identify what information should be collected to evaluate products. Lack of this ability would lead them to seek advice from clerks in brick-and-mortar stores or from acquaintances. On the other hand, price-comparison-site seekers showed the significantly lowest score on location and access, which is the ability to identify the range and characteristics of information channels. Thus, they would prefer to visit price-comparison websites that provide a summary of relevant information. 
Table 2. Differences of CIL between the clusters

\begin{tabular}{|c|c|c|c|c|c|c|c|c|c|c|}
\hline \multicolumn{2}{|c|}{$\begin{array}{l}\text { Consumer } \\
\text { information } \\
\text { literacy }\end{array}$} & \multicolumn{2}{|c|}{$\begin{array}{c}\text { Price- } \\
\text { comparison- } \\
\text { site seeker }\end{array}$} & \multicolumn{2}{|c|}{$\begin{array}{l}\text { Information } \\
\text { checker }\end{array}$} & \multicolumn{2}{|c|}{$\begin{array}{c}\text { Consumer } \\
\text { information } \\
\text { seeker }\end{array}$} & \multicolumn{2}{|c|}{$\begin{array}{l}\text { Heavy } \\
\text { searcher }\end{array}$} & \multirow{2}{*}{$\begin{array}{c}\mathrm{F} \\
9.89^{* * *}\end{array}$} \\
\hline Task definition & $4.93(.91)$ & $4.85(.94)$ & $\mathrm{b}$ & $4.51(.88)$ & $\mathrm{a}$ & $5.07(.96)$ & $\mathrm{bc}$ & $5.17(.79)$ & $\mathrm{c}$ & \\
\hline $\begin{array}{l}\text { Information } \\
\text { seeking strategy }\end{array}$ & $4.59(1.07)$ & $4.31(1.12)$ & $\mathrm{a}$ & $4.29(1.02)$ & $\mathrm{a}$ & $4.54(1.17)$ & $\mathrm{a}$ & $4.97(.91)$ & b & $8.34^{* * *}$ \\
\hline $\begin{array}{l}\text { Location and } \\
\text { access }\end{array}$ & $4.58(.98)$ & $4.01(1.13)$ & $\mathrm{a}$ & $4.41(.86)$ & $\mathrm{b}$ & $4.49(1.00)$ & $\mathrm{b}$ & $4.99(.84)$ & $\mathrm{c}$ & $13.74^{* * *}$ \\
\hline $\begin{array}{c}\text { Use of } \\
\text { information }\end{array}$ & $4.70(.89)$ & $4.52(.95)$ & $a b$ & $4.35(.77)$ & $\mathrm{a}$ & 4.78(.94) & $\mathrm{bc}$ & $4.96(.83)$ & $\mathrm{c}$ & $8.73^{* * *}$ \\
\hline Synthesis & $4.90(.94)$ & $4.77(1.03)$ & $\mathrm{a}$ & $4.52(.86)$ & $\mathrm{a}$ & $5.10(.97)$ & $\mathrm{b}$ & $5.09(.85)$ & $\mathrm{b}$ & $8.20^{* * *}$ \\
\hline Evaluation & $4.72(1.02)$ & $4.67(1.01)$ & $\mathrm{b}$ & $4.27(.93)$ & $\mathrm{a}$ & $4.86(1.07)$ & $\mathrm{b}$ & 4.97(.96) & b & $8.73^{* * *}$ \\
\hline \multicolumn{2}{|c|}{ Mean of overall CIL } & 4.54 & $\mathrm{a}$ & 4.41 & $\mathrm{a}$ & 4.82 & $\mathrm{~b}$ & 5.03 & b & $11.94^{* * *}$ \\
\hline
\end{tabular}
${ }^{* * * *} \mathrm{p}<.001$

\section{CONCLUSION}

The current study classifies South Korean consumers in their twenties and thirties based on their information channel use when they choose laptop computers and examines demographic characteristics and difference of CIL between the groups.

Results revealed that consumers with the high level of CIL actively searched information channels. Since information search is required to make satisfactory purchase decision, it is necessary to develop educational program to enhance consumers' ability to search and to utilize information. Especially, it was found that pricecomparison-site seekers lack the abilities to identify a range of usable information channels and to locate appropriate information within the channels. Thus, it would be necessary for them to improve competency to collect information from more diverse channels so they can make better purchase decisions. Also, it would be important to educate clerks in brick-and-mortar stores to provide reliable information for consumers who visit the stores to confirm their product knowledge or to get recommendation from the clerks.

This study contributes to extending the understanding of product information search behavior of consumers in their twenties and thirties and provides insights into the relationship between search behavior and the ability to efficiently search for product information.

\section{REFERENCES}

Kang, J., 2010. The Role of Information Literacy Competence in Technology Acceptance Model. The Journal of Internet Electronic Commerce Research, Vol. 10, No. 4, pp 13-33.

Lee, J., and Rha, J., 2012. Consumers' Channel Choice and Channel Positioning in Multichannel Environment. Journal of Consumer Policy Study, Vol. 41, pp 143-169.

Hwang, H. S., and Kim, K., 2012. Consumer Information Competency of Contemporary Consumers: Effects on Information Search Efficiency and Effectiveness for Purchase of Electronic Goods. Journal of the Korean Home Economics Association, Vol. 50, No. 6, pp 99-117. 